\title{
Grass survey of the Itremo Massif records endemic central highland grasses
}

\author{
Olinirina P. Nanjarisoa', Guillaume Besnard", Hélène \\ Ralimanana!, Vololoniaina H. Jeannodall' and Maria S. \\ Vorontsovalv
}

\author{
Correspondence: \\ Maria S. Vorontsova \\ Royal Botanic Gardens, \\ Richmond, Surrey TW9 3AB \\ United Kingdom \\ Email: m.vorontsova@kew.org
}

\begin{abstract}
Despite the substantial area covered by grasslands in Madagascar (65\%), the taxonomy of the grasses (Poaceae), which represent the main plant component of these vegetation types, is still understudied. Inventories and detailed specimen identification work from 12 localities in the Itremo Massif Protected Area allowed us to compile a list of grasses present in the area. In total, members of eight subfamilies, 56 genera, and 99 species have been recorded from the Itremo Massif. Grasslands cover $75 \%$ of the Itremo Massif Protected Area and are dominated by Panicoideae (65\%) and by $\mathrm{C}_{4}$ plants. The genera Eragrostis and Panicum, with nine and eight species respectively, are the best represented genera in Itremo. Eragrostis betsileensis and Tristachya betsileensis are the two species known to be local endemics. Twenty species are endemic to the central highlands, and a further 14 species are restricted to Madagascar. Five ecological groups of grasses were identified in the Itremo Massif: shade species in gallery forests, open wet area species, fire grasses, anthropogenic disturbance associated grasses and rock-dwelling grasses. Grasslands of the Itremo Massif are likely to be at least partly natural as shown by their richness in terms of endemic and native grass species. Conservation of such grasslands is thus an important issue, not only for grasses but for all species that inhabit these open canopy habitats.
\end{abstract}

\section{RÉSUMÉ}

Malgré la superficie importante occupée par les formations herbeuses de Madagascar (65\%), la taxonomie des graminées (Poaceae) dominant ces écosystèmes reste mal connue. Les inventaires effectués dans 12 localités de l'Aire Protégée (AP) du Massif d'Itremo et les travaux d'identification nous ont permis de dresser une liste des espèces de Poaceae de la région. Au total, la liste établie est composée de huit sous-familles, 56 genres et 99 espèces dont la sous-famille des Panicoideae (65\%) et des espèces à photosynthèse en $\mathrm{C}_{4}$ sont les taxons dominants. Les genres Eragrostis et Panicum, avec respectivement neuf et huit espèces, sont les mieux représentés. Eragrostis betsileensis et Tristachya betsileensis sont les seules espèces localement endémiques, tandis que 20 espèces sont endémiques des hautes terres du centre, et 14 sont endémiques de Madagascar. Cinq groupements de Poaceae qui correspondent à des milieux différents ont été identifiés au sein de I'AP : les espèces ombrophiles des forêts galeries, les espèces de milieux humides ouverts, les espèces associées au feu, les espèces rupicoles et les espèces anthropiques. Les formations herbeuses de l'Itremo seraient au moins en partie d'origine naturelle et ancienne, comme le suggère leur richesse en espèces endémiques et indigènes, et méritent donc d'être conservées, non seulement pour les Poaceae mais pour toutes les autres espèces qui y cohabitent.

\section{INTRODUCTION}

Grasses are members of the plant family Poaceae, and are primarily known for their critical role in food provision. Cultivated rice Oryza sativa L., maize Zea mays L., and sugar cane Saccharum officinarum L. are all members of this family. In 2015, 1.104 billion tonnes of these cereals were produced for human consumption (FAO 2015). The second critical role of grasses is their cornerstone function in many of the world's ecosystems. Grasslands as defined by the FAO cover about $26 \%$ of the land on Earth (FAOSTAT 2000), and 65\% of Madagascar (Moat and Smith 2007). Open canopy vegetation types with a grassy understory have a history of being undervalued compared to closed canopy forest, even when they are known to represent ancient ecosystems (Bond and Parr 2010, Parr et al. 2014, Bond 2016). Many grassy biomes have only recently been recognised as natural and valuable ecosystems (e.g., Bond et al. 2008, Vorontsova et al. 2016). Multiple authors documenting the vegetation of Madagascar (e.g., Koechlin et al. 1974) have traditionally assumed that Malagasy grasslands are degraded formations resulting from the destruction of climax forests.

\footnotetext{
Kew Madagascar Conservation Centre, Antananarivo 101, Madagascar

U UMR5174, EDB (Laboratoire Évolution et Diversité Biologique), CNRS-UPS-ENSFEA-IRD, Toulouse, France

III Department of Plant Biology and Ecology, University of Antananarivo, Antananarivo 101, Madagascar

IV Royal Botanic Gardens, Kew, Richmond, United Kingdom

Citation Nanjarisoa, O. P., Besnard, G., Ralimanana, H., Jeannoda, H. V. and Vorontsova, M. S. 2017. Grass survey of the Itremo Massif records endemic central highland grasses. Madagascar Conservation \& Development 12, 1: 34-40. http://dx.doi.org/10.4314/mcd.v12i1.6
} 


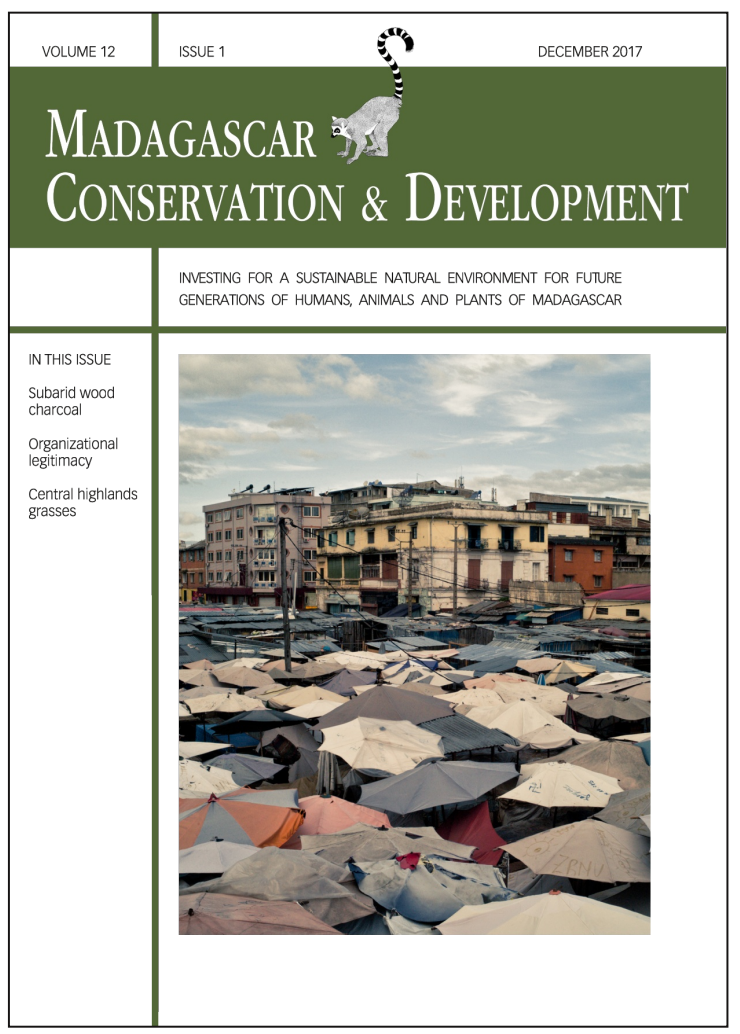

Madagascar Conservation \& Development is the journal of Indian Ocean e-Ink. It is produced under the respon-sibility of this institution. The views expressed in contri-butions to MCD are solely those of the authors and not those of the journal editors or the publisher.

All the Issues and articles are freely available at http://www.journalmcd.com

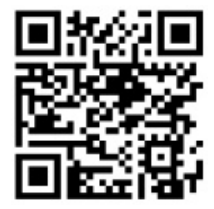

Contact Journal MCD

info@journalmcd.net for general inquiries regarding MCD funding@journalmcd.net to support the journal

Madagascar Conservation \& Development Institute and Museum of Anthropology

University of Zurich

Winterthurerstrasse 190

$\mathrm{CH}-8057$ Zurich

Switzerland

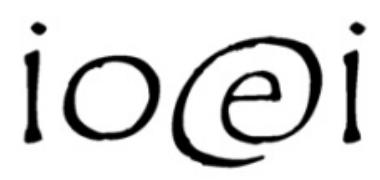

Indian Ocean e-Ink

Promoting African Publishing and Education

www.ioeink.com

Missouri Botanical Garden (MBG)

Madagascar Research and Conservation Program

Missouri Botanical Garden BP 3391

Antananarivo, 101, Madagascar 
Despite their critical role in the landscape, Malagasy grasses have been poorly studied taxonomically, causing a significant species knowledge gap not only in the flora of Madagascar but also in that of the world (Bond et al. 2008). The only comprehensive taxonomic reference published to date is that by Bosser (1969) in his book Graminées des pâturages et des cultures à Madagascar, which is limited to the central highlands and accounts for approximately half of the island's grass species diversity. Recent progress has been made in documenting Madagascar's bamboos, but much remains to be done (Dransfield 1998, 2000, 2003). Accurate grass identification requires careful microscope observation of the reproductive organs, in addition to high quality collection of reference specimens. The superficial similarity of unrelated taxa, the complexity and small size of the flowering structures, and the frequently incomplete specimens can make the identification process challenging, and this has previously discouraged collecting activity. In the national herbarium of the Parc Botanique et Zoologique de Tsimbazaza, Antananarivo (TAN), the majority of grass collections identified to species level are relatively old, largely collected between 1960 and 1970 by the French botanists Jean Bosser and Philippe Morat. This study is part of an ongoing project seeking to document grasses and grasslands of Madagascar, working towards a taxonomic revision of all Poaceae of Madagascar (Vorontsova et al. 2013, Vorontsova and Rakotoarisoa 2014), carried out by the Royal Botanic Gardens Kew and the Kew Madagascar Conservation Centre (KMCC).

This study evaluates the grass diversity in the Itremo Massif Protected Area. We establish a list of species, present an identification key, and survey ecological preferences of the species, building a knowledge platform to study the origin of grasslands in this area.

\section{STUDY SITE}

The Itremo Massif Protected Area (PA), managed jointly by the local community and KMCC, was chosen to study the grasses of the Malagasy central highlands. The Itremo Massif PA covers an area of 24788 ha dominated by grassy biomes (70\% of the land area). The choice was justified by an increasing knowledge base of Itremo's flora following ongoing study by the KMCC (Kew Madagascar Conservation Centre 2012). The Itremo Massif PA has been established as a protected area in 2015 (established by decree $n^{\circ}$ 2015-713 of the Ministry of Environment, Ecology, Sea and Forests), and is located in the southern part of the central highlands. The Itremo Massif is $117 \mathrm{~km}$ west of Ambositra, Ambatofinandrahana district, Amoron'i Mania Region, ex-Province of Fianarantsoa, between E046 ${ }^{\circ} 38^{\prime} 10^{\prime \prime}$ and E046 ${ }^{\circ} 14^{\prime} 35^{\prime \prime}$ Iongitude, and $\mathrm{S}_{2} \mathrm{O}^{\circ} 35^{\prime} 40^{\prime \prime}$ and $\mathrm{S} 20^{\circ} 35^{\prime} 36^{\prime \prime}$ latitude (Figure 1).

The Itremo Massif PA is surrounded by three villages and two rivers: Itremo village in the east, Amborompotsy and Mangataboahangy villages in the west, Mania river in the north and Matsiatra river in the south. The landscape is dominated by plains interspersed with rocky outcrops. These are composed of micaschistes (at lower elevation; ca. 500 m), quartzite (from 700 to $1500 \mathrm{~m}$ ), dolomitic marbles (from 900 to $1000 \mathrm{~m}$ ) and marbles at the summit (> 1500 m; Birkinshaw et al. 2008). Itremo Massif has a subhumid bioclimate, characterized by dry and rainy seasons, an annual average temperature of $19.5^{\circ} \mathrm{C}$ and an annual average rainfall of $1416 \mathrm{~mm}$, with December, January and February being the wettest months of the year (Cornet 1974; Birkinshaw et al. 2008).

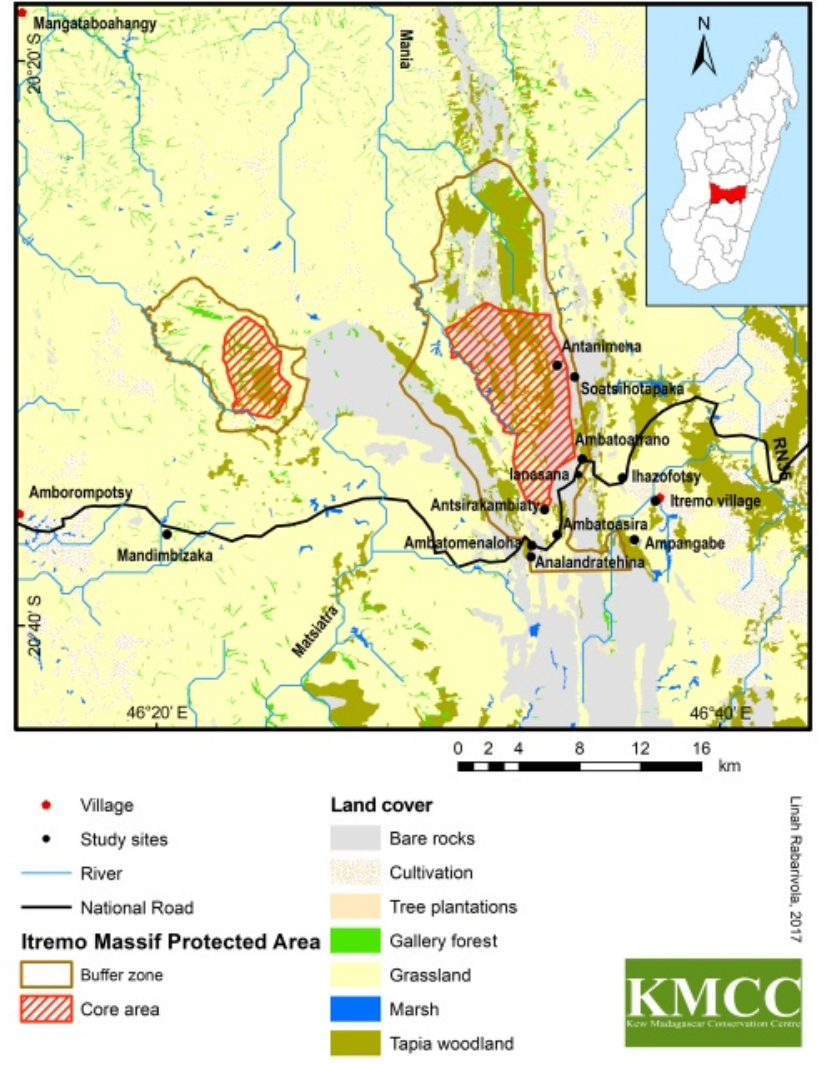

Figure 1. Vegetation map of the Itremo Massif Protected Area. (Map by Linah Rabarivola and the Kew Madagascar Conservation Centre. Study sites are marked with black circles; the checklist also includes older herbarium specimens collected throughout the area with no specific location data)

The Itremo Massif PA is home to 549 known species of plants in 278 genera and 99 families, with $77 \%$ of species endemic to Madagascar, and 30 local endemics (Kew Madagascar Conservation Centre 2012). The vegetation of Itremo Massif is composed of gallery forests, tapia forests, grasslands, swamps, and rock outcrops, as well as secondary vegetation types (Birkinshaw et al. 2008, Kew Madagascar Conservation Centre 2012).

\section{METHODS}

A field inventory of the grasses was carried out in all habitats of Itremo during repeated visits by the first author in March 2013, February 2014, and June 2014. Local sites surveyed include Ambatoatrano, Ambatoasira, Ambatomenaloha, Ampangabe, Analandratehina, Antanimena, Antsirakambiaty, Ianasana, Ihazafotsy, Itremo village, Mandimbizaka, Soatsihotapaka (Figure 1). Every fertile grass suspected of being a distinct species was collected to make herbarium vouchers distributed to Tsimbazaza (TAN), Kew (K) and Paris (P) herbaria (abbreviations fide Thiers 2015). Habitat metadata, photographs, and silica gel samples were collected, and data were recorded in a BRAHMS (2015) database. Images of all the genera are available online at $<$ https://goo.gl/uqyCtJ>. Previous collections of grasses in Itremo made by M. S. Vorontsova and by KMCC were added to the dataset as well as all Itremo Poaceae specimens held at $K$ and $P$ herbaria. Occurrence records were used to compile a list of species characteristic of each habitat type.

Reliable species-level identification of the grasses requires dissection of the spikelet, as the spikelet contains almost all characters distinguishing genera and species. Spikelet structure was recorded, including the composition of glumes, florets, lemmas, 
paleas, the number of veins and the placement of indumentum, and the size of all spikelet parts. Full drawings of the spikelet dissections were made for at least one member of each genus (example presented in Figure 2). Identification was carried out by reference to existing herbarium collections, and using keys in Bosser (1969), Clayton (1970), Clayton et al. (1974), Clayton and Renvoize (1982), Vorontsova et al. (2013) and Kellogg (2015). The keys were modified and adapted to create an identification key to Poaceae species of Itremo (Supplementary material). Species distribution data are from the World Checklist of Selected Plant Families (2017) and from taxonomic work by the authors. Data on the photosynthetic system is from Osborne et al. (2014) and Kellogg (2015).

\section{RESULTS}

POACEAE DIVERSITY. The grasses are a species-rich family represented in the Itremo Massif PA by 56 genera and 99 species (Table S1). These can be identified using the keys provided in the Supplementary Material. Grasses are the most diverse plant family in the Itremo Massif PA. Within the Poaceae these species belong predominantly to the tropical PACMAD clade (Panicoideae, Arundinoideae, Chloridoideae, Micrairoideae, Aristidoideae, and Danthonioideae, 92\%), with some also belonging to the temperate BEP clade (Bambusoideae, Ehrhartoideae, and Pooideae, 8\%). They belong to eight subfamilies and 14 tribes within the Poaceae according to the classification by Kellogg (2015). With 64 species, the common tropical mesic environment group Panicoideae is the best represented subfamily, followed by the tropical arid subfamily Chloridoideae with 20 species. The temperate Pooideae and the bamboos (Bambusoideae) are represented by just five and three species, respectively. Aristidoideae, Arundinoideae and Micrairoideae are represented by two species each. The rice relatives Ehrhartoideae are represented in the Itremo Massif PA by only one native species, Leersia hexandra. The genera Eragrostis and Panicum sensu lato are the most diverse with nine and eight species respectively. Common tropical grass genera of Africa including Andropogon, Brachiaria (note these have not been moved to the genus Urochloa due to their diverse phylogenetic placements not currently fully resolved), Oplismenus, Setaria, Sporobolus, Digitaria and Hyparrhenia are moderately diverse and represented
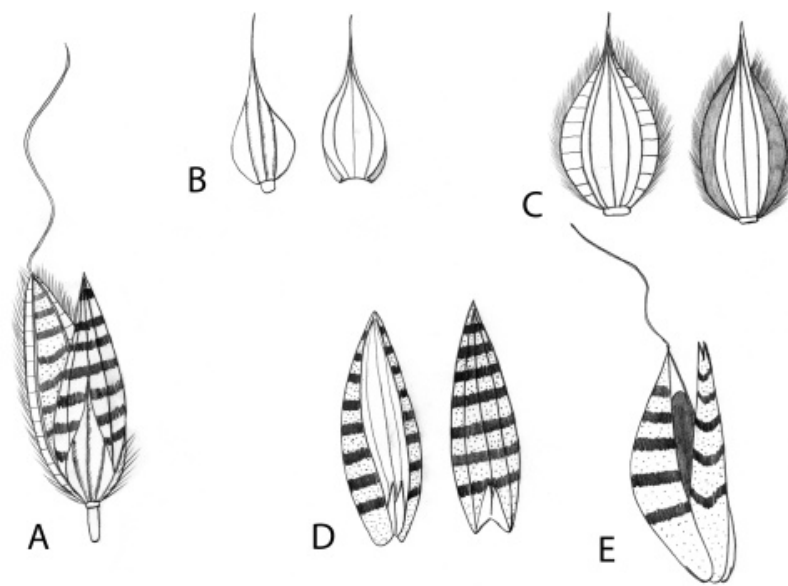

Figure 2. Spikelet dissection of Alloteropsis semialata, illustrating dissection work carried out in order to identify grasses through their spikelet structure. (A: spikelet (9 mm long including awn); B: lower glume, dorsal and ventral views (4.5 mm long); C: upper glume, dorsal and ventral views (6 mm long); D: lower floret, ventral and dorsal views ( $5 \mathrm{~mm}$ long); E: upper floret, the upper lemma with awn shown on the left hand side, the immature grain inside $(9 \mathrm{~mm}$ long including awn). Drawing by Nanjarisoa Olinirina Prisca from Nanjarisoa 23, Ampangabe, collection made on 26 March 2013) by three to five species each. The remaining 47 genera are represented by a single species each. Species with the $\mathrm{C}_{4}$ photosynthetic system predominate with 68 species, suggesting a flora adapted to open and seasonally dry habitats.

POACEAE BIOGEOGRAPHIC AFFINITIES. The ecological preferences and distribution ranges of the 99 species of Poaceae in the Itremo Massif PA are presented in Table S1 and Figure 3. Two of the species (2\%) are narrow endemics only known from the Itremo Massif PA: Eragrostis betsileensis and Tristachya betsileensis (Figure 4). Despite the comparatively low local endemicity, 22 of the species recorded (22.2\%) are restricted to the central highlands and a further 12 (12.1\%) are endemic to Madagascar. Overall, 36 of the grass species (36.4\%) are endemic to the island. The majority of the species (59 species, $59.6 \%$ ) are thought to be native to Madagascar and also occur in other parts of the world, predominantly in tropical Africa. Only four species have been recorded as likely introduced, a figure which is highly uncertain due to poor records of species origins. The native versus introduced status of Madagascar's grasses is largely unknown and challenging to establish. We have tentatively assigned native status to the majority of African grasses following notes by Bosser (1969), long term taxonomic work by the last author, the authors' personal impression of similarity to African ecosystems, and limited data indicating significant genetic diversity within Malagasy Aristida (Besnard et al. 2014, Hackel et al. 2017).

POACEAE HABITAT PREFERENCES. The greatest diversity of grasses was recorded in fallow fields (41 species, $41.4 \%$ ) and roadsides (37 species, $37.4 \%$ ). Both of these habitats are rich in $\mathrm{C}_{4}$ grasses, particularly from the subfamily Chloridoideae, which are adapted to arid conditions. The characteristic species of fallow fields and roadsides are those commonly observed in disturbed areas all over Madagascar: Chloris pycnothrix, Cynodon dactylon, Eragrostis tenuifolia and Cenchrus polystachios (Table 1). Environmental heterogeneity was noted as particularly high in the disturbed areas, likely indicating increased species turnover with

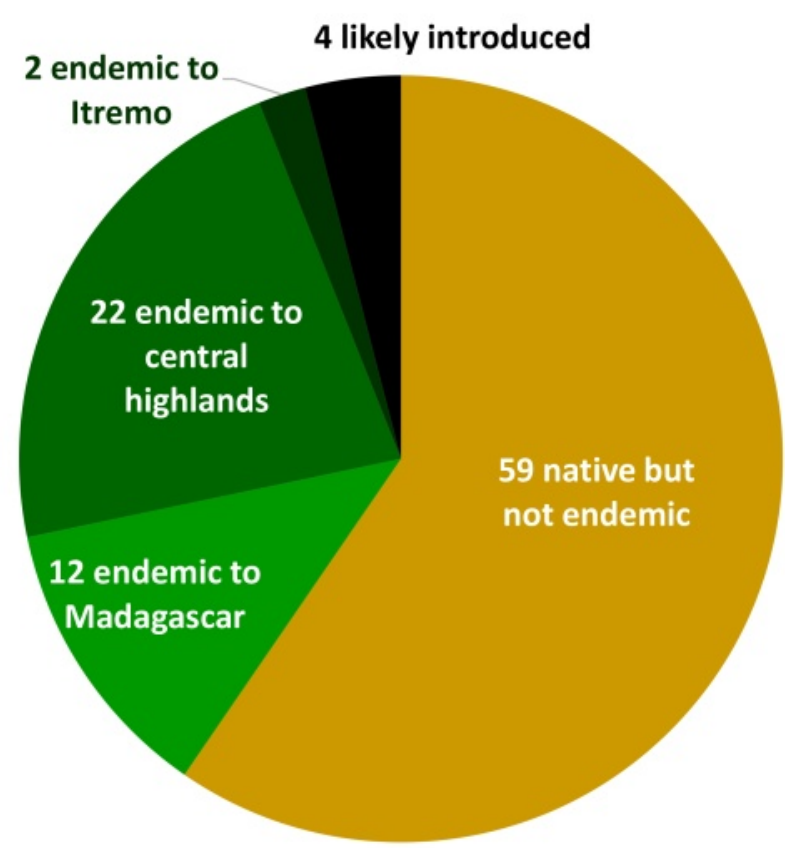

Figure 3. Distribution ranges and likely native/introduced status of the 99 grass species recorded in Itremo. 


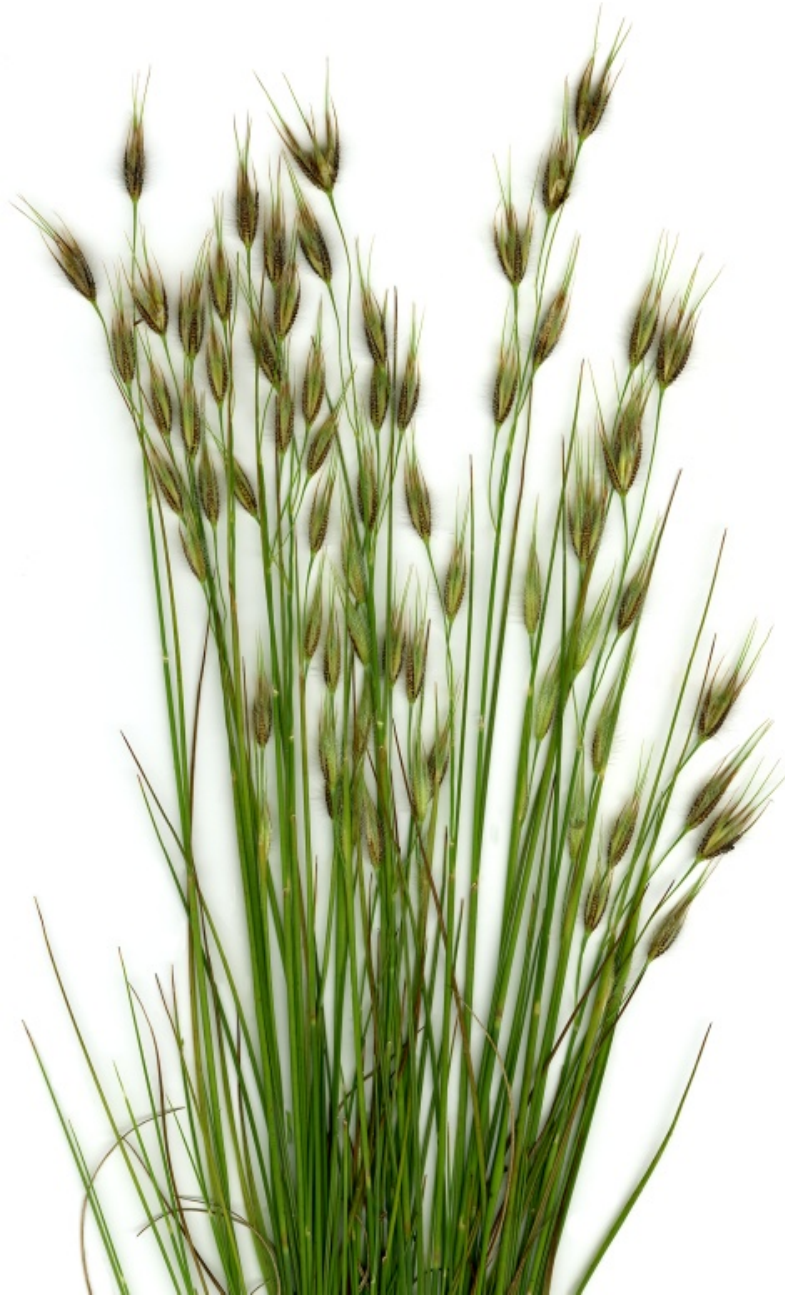

Figure 4. Tristachya betsileensis, locally endemic to Itremo. (Spikelets $12 \mathrm{~mm}$ long; live plant scanned using an Epson 10000XL scanner)

dispersal occurring along the road and associated with movement of zebu. The natural habitat with the greatest species diversity was the tapia forest (37 species) and the majority of its grasses were the same as those found in the grassland (34 species). Five species endemic to the highlands were reported in tapia and grasslands, these two habitats sharing a similar continuous grassy understory: Andropogon ibityensis, A. itremoensis, Panicum cinctum, $P$. ibityense, and $P$. perrieri. The highest endemicity was observed on the rocky outcrops. Almost all rocky outcrop grasses sampled are endemic to the central highlands. The Itremo endemic Tristachya betsileensis is restricted to these outcrops (Fig- ure 4). One $C_{3}$ species (Styppeiochloa hitchcockii) highly tolerant of desiccation and able to recover rapidly was also reported in this habitat. The grass flora of gallery forests and marshes, swamps and streamsides (group I: high moisture habitats protected from fire) is clearly distinct from tapia, grassland, rocky outcrops, and disturbed places (group II: dry and sunny habitats with regular fire). Habitats associated with high moisture and no fire are home to a notably diverse Poaceae flora with 33 species recorded in the gallery forests and 32 species in open wet habitats. These are also home to the greatest diversity of subfamilies: Bambusoideae (bamboos) and Ehrhartoideae (rice relatives) have only been recorded in the high moisture and no fire habitats. Species judged to be characteristic of each habitat and their environmental correlates are presented in Table 1.

\section{DISCUSSION}

POACEAE DIVERSITY. The Itremo floristic data summary compiled by the Missouri Botanical Garden in 2008 listed 27 species of Poaceae (Birkinshaw et al. 2008). This study has increased threefold the number of grasses recorded, now reaching 99 species. Twenty of these species (including the three endemic bamboos) do not appear in the standard reference book of Madagascar grasses by Bosser (1969). The sharp increase in the number of recorded species has been achieved by our first ever targeted Poaceae survey of this area, which redressed a longterm bias against botanical collecting in similar grassland areas, previously assumed to be botanically depauperate (e.g., Lowry et al. 1997). Specialist skills of spikelet structure observation, working with Poaceae taxonomic reference literature, as well as the use of international herbaria have also made this possible, since some of the species were not represented or not correctly named at TAN. We demonstrate that specialist studies of grasses can reveal previously undocumented diversity. This study presents the first reference list of Itremo Poaceae species and their habitats, to be used in the management of the PA as well as for future diversity and ecosystem research. The subfamily and genus identification keys written during this study are the first for the Itremo Massif PA. We hope that with these keys, other botanists will be able to identify grasses from Itremo and other parts of the highlands.

The new total of 99 Poaceae species in Itremo PA is significantly higher than previous regional grass studies published for Madagascar. This likely reflects a lack of deliberate effort to record the grasses by Lewis et al. (1996) who listed only 18 species in Andringitra National Park, and Gautier (1997) who listed 42 species in the Manongarivo Reserve. The Poaceae specialist Morat (1973) lis-

Table 1. Poaceae species judged to be characteristic of Itremo's habitats.

\begin{tabular}{|c|c|c|c|}
\hline Groups & Subgroups & Habitats & Characteristic species \\
\hline \multirow{5}{*}{$\begin{array}{l}\text { Group I: Damp area } \\
\text { grasses, require } \\
\text { permanent soil moisture }\end{array}$} & Subgroup 1: Shade species, & Gallery forest & Brachiaria epacridifolia, Brachypodium madagascariense, Isachne \\
\hline & require significant shade, do & & mauritiana, Hickelia madagascariensis, Oldeania itremoensis, Oplismenus \\
\hline & not tolerate strong sunlight & & hirtellus, Oplismenus flavicomus, Oplismenus compositus, Saccharum \\
\hline & & & perrieri, Acroceras boivinii, Pseudobromus breviligulatus, Panicum mitopus \\
\hline & $\begin{array}{l}\text { Subgroup 2: Open wet } \\
\text { habitat }\end{array}$ & $\begin{array}{l}\text { Marshes and swamps, } \\
\text { streamsides }\end{array}$ & $\begin{array}{l}\text { Adenochloa hymeniochila, Calamagrostis emirnensis, Ischaemum } \\
\text { polystachyum, Setaria sphacelata, Trichopteryx dregeana }\end{array}$ \\
\hline \multirow[t]{3}{*}{$\begin{array}{l}\text { Group II: Dry area grasses, } \\
\text { require prolonged } \\
\text { exposure to sunlight }\end{array}$} & $\begin{array}{l}\text { Subgroup 3: Anthropogenic } \\
\text { grasses (highly tolerant to } \\
\text { disturbance); i.e., ruderal } \\
\text { species, weeds of } \\
\text { cultivation and roadside }\end{array}$ & Roadsides, fields & Chloris pycnothrix, Cynodon dactylon, Cenchrus polystachios \\
\hline & $\begin{array}{l}\text { Subgroup 4: Fire grasses; } \\
\text { tolerant of frequent burning } \\
\text { or dependent on it }\end{array}$ & Tapia forest, grassland & $\begin{array}{l}\text { Andropogon ibityensis, Andropogon itremoensis, Ctenium concinnum, } \\
\text { Digitaria ciliaris, Digitaria pseudodiagonalis, Panicum cinctum, Panicum } \\
\text { ibityensis }\end{array}$ \\
\hline & Subgroup 5: Rock grasses & $\begin{array}{l}\text { Rocky outcrops, schiste, } \\
\text { quartzite, marble, basalt }\end{array}$ & $\begin{array}{l}\text { Andropogon ivohibensis, Oldeania ibityensis, Setaria bathiei, Styppeiochloa } \\
\text { hitchcockii }\end{array}$ \\
\hline
\end{tabular}


ted 43 species in Madagascar's southwestern grasslands (species list adjusted to modern taxonomic concepts), which is close to the 34 species we record in Itremo grassland and 37 in Itremo tapia forest. The overall species richness and subfamily composition of Madagascar's grass flora is remarkably close to that of East Africa (Bond et al. 2008; Vorontsova et al. 2016) and most of Madagascar's endemic grass lineages have arrived from tropical Africa (Hackel et al., 2017), leading to the expectation that regional grass checklists in Madagascar may be similar to those in Africa. Specialist Poaceae checklists in three much larger areas of Tanzania have recorded 123 grass species in the Mkomazi National Park (Vollesen et al. 1999), 200 in the Serengeti Ecosystem (Williams et al. 2016), and 239 in the Selous Game Reserve (Vollesen 1980). This is the first study to present regional grass diversity in Madagascar as comparable to equivalent ecosystems in Tanzania.

POACEAE ENDEMICITY. Poaceae endemicity for Itremo is documented here for the first time: 36 species (36.4\%) are endemic to Madagascar, and these are present across all vegetation types except the disturbed roadsides and fallow fields. More than a quarter (28\%) of the species found in the grasslands are endemic, 38\% of those in the tapia forests are endemic, as well as $30 \%$ of those on rocky outcrops. For Madagascar as a whole, 217 of 541 grass species are endemic. This country wide endemicity level of $40 \%$ is low compared to Madagascar's other plant families (e.g., Buerki et al. 2013), but Poaceae are unlike other families in their broad distribution ranges and lower levels of endemism across the world (e.g., Sandel et al. 2017). Poaceae endemicity in the Malagasy floristic region is in fact in line with other subtropical islands, or somewhat higher than other subtropical islands (Vorontsova et al. 2016). Hence Poaceae endemicity in Itremo is in line with the expectations for a Malagasy natural grass flora.

POACEAE SPECIES ECOLOGY. Our species inventory has documented a complex flora with a different group of grasses defining each of Itremo's habitats, in accordance with their adaptations and evolutionary niches. There is a broad division between two types of strategies: $\mathrm{C}_{3}$ often broad-leaved forest grasses and bamboos tend to be restricted to high moisture, often shaded, fire protected gallery forest and riverine environments (Table 1: group I), while generally $\mathrm{C}_{4}$ frequently erect and caespitose species are found in drier open-canopy regularly burned ecosystems (Table 1: group II). Each of these two habitat types is home to endemic species, but the frequently burned habitats of group II have a particularly large number of species restricted to the highlands: Andropogon ibityensis, Andropogon itremoensis, Panicum cinctum, Panicum ibityense, Andropogon ivohibensis, Oldeania ibityensis, Setaria bathiei, and Styppeiochloa hitchcockii. Grasses of the quartz and marble rock outcrops have the most restricted distribution ranges. Tapia forest and grassland have almost the same continuous Poaceae ground layer, although some species preferentially grow in the tapia forest (i.e., Panicum ibityense and P. perrieri)

GRASSLAND ORIGINS AND CONSERVATION. Total Poaceae diversity in Itremo correlates with fire, sharp elevational gradients, strong disturbance, and high exposure to sunlight, as expected for a largely $\mathrm{C}_{4}$ flora with anatomic and biochemical adaptations that allow limiting photorespiration in exposed environments (Sage et al. 1999; Sage 2004). Sixty-eight species (69\%) of the Itremo Poaceae have a $\mathrm{C}_{4}$ photosynthetic system, including seventeen out of 36 Madagascar endemics (47\% of Itremo endemic grasses are $C_{4}$ ). Hackel et al. (2017) have documented $45 C_{4}$ grass lineages endemic to Madagascar, with divergences and crown ages compatible with the Miocene grassland expansion 3-8 million years ago (Edwards et al. 2010, Strömberg 2011). It seems plausible that Itremo's $\mathrm{C}_{4}$ grasses diversified and established the grass-dominated ecosystems as part of the global Miocene grassland expansion. However, it is worth noting here that the model of $\mathrm{C}_{3}$ versus $\mathrm{C}_{4}$ photosynthetic types signifying open versus closed canopy vegetation is an oversimplification: the different $\mathrm{C}_{4}$ grass clades have different $\mathrm{C}_{4}$ subtypes which occupy quite different ecophysiological niches (Visser et al. 2012, Christin and Osborne 2014). The history of Madagascar's grasses and grasslands is a complex story which needs to be studied carefully by detailed functional ecology studies for the different ecoregions and habitats, clades, and functional groups.

Malagasy grassland has traditionally been assumed to constitute secondary vegetation resulting from human-driven forest degradation (Perrier de la Bâthie 1921, Humbert 1927, Koechlin et al. 1974). A relatively recent shift in thinking has suggested that considerable parts of Malagasy grasslands could be both natural and ancient (Bond et al. 2008, Willis et al. 2008), likely part of the global $\mathrm{C}_{4}$ grass biome expansion during the Late Miocene-Pliocene (Strömberg 2011, Hoetzel et al. 2013). The commonly cited figure of $90 \%$ forest loss across Madagascar has now been thoroughly discredited (McConnell and Kull 2014) and may be nothing but a bibliographic myth (Lowry et al. 1997). Understanding the difference between old growth grasslands and superficially similar secondary vegetation (severely degraded forests, or derived open woodlands) is a complex task (Veldman 2016) which is outside the scope of this study. It is generally agreed that old growth grasslands frequently differ from secondary vegetation by their greater species diversity, and greater species endemicity (e.g., Parr et al. 2014, Veldman et al. 2015, Veldman 2016). Our results demonstrate a high diversity (34 species) and a significant level of endemicity (13 species, $40 \%$ ) of Poaceae in grasslands of the Itremo Massif PA. Our results thus lend support to possible natural origins of Itremo grasslands. Experimental studies on vegetation response to fire and disturbance regimes are required for further understanding of the likely history of these systems.

These ecosystems need protection to preserve their unique species. Tapia forests and rocky outcrops are already included in the conservation target sites in the Itremo Massif PA, and we suggest grassland could be included in the future. A grassland conservation strategy can only be achieved by first gaining a greater understanding of grassland histories and functional types, something which has not previously been attempted for the central highlands. Moat and Smith (2007) admit their failure to distinguish between the many kinds of open canopy vegetation primarily due to their high seasonality, and a specialist study of these formations is needed. Yet another research gap currently preventing the formation of a grassland conservation strategy is our lack of knowledge of herbaceous non-grass plants found in the grassland understory.

\section{CONCLUDING REMARKS}

The first specialised taxonomic inventory of the Itremo Massif Poaceae has revealed this family to be the most diverse of the new protected area, with 99 species in 56 genera and all but four of 
these believed to be native to the area. Endemicity is low compared to other plant families but in line with the rest of Madagascar's grasses, and high compared to grasses in other parts of the world: $36.4 \%$ of the species are endemic to Madagascar, including $22.2 \%$ which are restricted to the central highlands, plus two local endemics. As expected, forest grasses intolerant of fire are largely $\mathrm{C}_{3}$ and form an ecological group distinct from the open canopy grasses which burn regularly and are largely $\mathrm{C}_{4}$. Significant levels of diversity and endemicity across multiple habitats are comparable to the complex and specialised grass floras of Tanzanian protected areas. The natural habitat with the greatest species diversity is the tapia woodland and the majority of its grasses are the same as those found in the grassland, suggesting ecological similarity between tapia and grassland. More than half of Itremo's grasses are $\mathrm{C}_{4}$, approximately half of all endemics are also $\mathrm{C}_{4}$, and these have likely diversified across Madagascar during the global Miocene grassland expansion around 3-8 million years ago. Our data are insufficient for any conclusions on ecosystem identity or origins: nevertheless, this first record of grass diversity and grass endemicity in the grasslands as well as all the other vegetation types is in line with what we would expect to see in natural ecosystems.

\section{ACKNOWLEDGMENTS}

This work was carried out by Nanjarisoa Olinirina Prisca towards a Diplôme d'études approfondies (D.E.A.) as a collaboration between the Department of Plant Biology and Ecology in the University of Antananarivo and the Kew Madagascar Conservation Centre (KMCC). It was generously financed by an Emily Holmes Memorial Scholarship to Nanjarisoa, and by National Geographic Society Global Exploration Fund - Northern Europe and BenthamMoxon Trust grants to Maria Vorontsova. Funding was also provided by a DREIC project (VSR28AFRIQ; UPS) to Guillaume Besnard. The authors would like to thank Stuart Cable (RBG Kew), and everyone at the Kew Madagascar Conservation Centre, and at Itremo PA for their support for this work. We would like to thank Direction Générale des Forêts (DGF) for granting research permits, and Parc Botanique et Zoologique de Tsimbazaza (PBZT) for supporting the permit applications, and also curators of $\mathrm{K}, \mathrm{P}$, and TAN herbaria for providing access to specimens.

\section{REFERENCES}

Besnard, G., Christin, P. A., Malé, P. J. G., Lhuillier, E., Lauzeral, C., Coissac, E. and Vorontsova, M. S. 2014. From museums to genomics: old herbarium specimens shed light on a C3 to C4 transition. Journal of Experimental Botany 65: 6711-6721. <http://dx.doi.org/10.1093/jxb/eru395>

Birkinshaw, C., Andriamihajarivo, T., Raharimampionona, J., Razafindrakoto, N., Ratolojanahary, M., et al.* 2008. Massif d'Itremo: presentation du site. Missouri Botanical Garden, Antananarivo.

Bond, W. J. 2016. Ancient grasslands at risk. Science 351: 120-122. $<$ http://dx.doi.org/10.1126/science.aad5132>

Bond, W. J. and Parr, C. L. 2010. Beyond the forest edge: Ecology, diversity and conservation of the grassy biomes. Biological Conservation 142: 2395-2404. <http://dx.doi.org/10.1016/j.biocon.2009.12.012>

Bond, W. J., Silander, J. A., Ranaivonasy, J. and Ratsirarson, J. 2008. The antiquity of Madagascar's grasslands and the rise of $\mathrm{C}_{4}$ grassy biomes. Journal of Biogeography 35: 1743-1758. <http://dx.doi.org/10.1111/j.1365-2699.2008.01923.x>

Bosser, J. 1969. Graminées des pâturages et des cultures à Madagascar. Mémoire ORSTOM. Paris.

BRAHMS (Botanical Research and Herbarium Management System). 2015. BRAHMS. <http://www.brahmsonline.com>
Buerki, S., Devey, D. S., Callmander, M. W., Phillipson, P. B. and Forest, F. 2013. Spatio-temporal history of the endemic genera of Madagascar. Botanical Journal of the Linnean Society 171: 304-329. $<\mathrm{http}: / /$ dx.doi.org/10.1111/boj.12008>

Christin, P.-A. and Osborne, C. P. 2014. The evolutionary ecology of $C_{4}$ plants. New Phytologist 204: 765-781. <http://dx.doi.org/10.1111/nph.13033>

Clayton, W. D. 1970. Flora of tropical East Africa: Gramineae, part 1. Crown Agents for Overseas Governments and Administrations, London.

Clayton, W. D. and Renvoize, S. A. 1982. Flora of tropical East Africa. Gramineae, part 3. AA Balkema, Rotterdam.

Clayton, W. D., Phillips, S. M. and Renvoize, S. A. 1974. Flora of Tropical East Africa. Gramineae, part 2. Royal Botanic Gardens, Kew.

Dransfield, S. 1998. Valiha and Cathariostachys, two new bamboo genera (Gramineae-Bambusoideae) from Madagascar. Kew Bulletin 5: 375-397.

Dransfield, S. 2000. Woody bamboos (Gramineae-Bambusoideae) of Madagascar. In: Grasses: Systematics and Evolution. S. W. L. Jacobs \& J. Everett (eds.). CSIRO. Melbourne.

Dransfield, S. 2003. Poaceae, Bambuseae, Bamboos. In: The natural history of Madagascar. S. M. Goodman \& J. P. Benstead (eds), pp 467-471. University of Chicago Press, Chicago.

Edwards, E. J., Osborne, C. P., Strömberg, C. A. E., Smith, S. A. et al. 2010. The origins of C4 grasslands: integrating evolutionary and ecosystem science. Science 328: 587-591. <http://dx.doi.org/10.1126/science.1177216>

FAO. 2015. Situation alimentaire mondiale. Bulletin de la FAO sur l'offre et la demande de céréales. Available at $<$ http://www.fao.org/worldfoodsituation/csdb/fr>

FAOSTAT. 2000. Brief analysis of FAO statistical data on pasture and Fodder crops. Available at <http://www.fao.org/uploads/media/grass_stats_pdf>

Gautier, L. 1997. Inventaire floristique de la Réserve Spéciale de Manongarivo (nord-ouest de Madagascar): Monocotyledonae. In: Documents EPB, no. 5. Institut Universitaire d'Études du Développement, Genève.

Hackel, J., Vorontsova, M. S., Nanjarisoa, O. P., Hall, R. C., Razanatsoa, J., Malakasi, P. and Besnard, G. 2017. Grass diversification in Madagascar: in situ radiation of two large $\mathrm{C}_{3}$ shade clades and support for a Miocene to Pliocene origin of C4 grassy biomes. Journal of Biogeography 45. <http://dx.doi.org/10.1111/jbi.13147>

Hoetzel, S., Dupont, L., Schefuss, E., Rommerskirchen, F. and Wefer, G. 2013. The role of fire in Miocene to Pliocene $\mathrm{C}_{4}$ grassland and ecosystem evolution. Nature Geoscience 6: 1027-1030. <http://dx.doi.org/10.1038/ngeo1984>

Humbert, H. 1927. Destruction d'une flore insulaire par le feu : principaux aspects de la végétation à Madagascar. Mémoires de l'Académie Malgache 5: 1-80.

Kellogg, E. A. 2015. Flowering plants. Monocots: Poaceae (Vol. 13). In: The Families and Genera of Vascular Plants. K. Kubitzki, (ed.). Springer.

Kew Madagascar Conservation Centre*. 2012. Plan d’Aménagement et de Gestion de la Nouvelle Aire Protégée du Massif d'Itremo-Ambatofinandrahana Région Amoron'l Mania, Madagascar. Unpubl. Report. Kew Madagascar Conservation Centre, Antananarivo.

Koechlin, J., Guillaumet J. L. and Morat, P. 1974. Flore et Végétation de Madagascar. A.R.G. Gantner Verlag, FL 9490 vaduz.

Lewis, B. A., Phillipson, P. B., Andrianarisata, M., Rahajasoa, G., Rakotomalaza, P. J. et al. 1996. A study of the botanical structure, composition and diversity of the eastern slopes of the Réserve Naturelle Intégrale d'Andringitra, Madagascar. Fieldiana 85: 24-75.

Lowry, P. P., Schatz, G. E., and Phillipson, P. B. 1997. The classification of natural and anthropogenic vegetation in Madagascar. In: Natural Change and Human Impact in Madagascar. S. M. Goodman and B. D. Patterson (eds.), pp 93-123. Smithsonian Institution Press, Washington DC.

McConnell, W. J. and Kull, C. A. 2014. Deforestation in Madagascar - debates over the island's forest cover and challenges of measuring forest change. In: I.R. Scales (ed.), Conservation and Environmental Management in Madagascar, pp 67-104. Routledge, Taylor \& Francis, Abingdon.

Moat, J. and Smith, P. 2007. Atlas of the Vegetation of Madagascar. Kew Publishing, Royal Botanic Gardens, Kew.

Morat, P. 1973. Les Savanes du Sud-ouest de Madagascar. Mémoires ORSTOM 68, Paris. 
Osborne, C. P., Salomaa, A., Kluyver, T. A., Visser, V., Kellogg, E. A., et al. 2014. A global database of $\mathrm{C}_{4}$ photosynthesis in grasses. New Phytologist 204: 441446. <http://dx.doi.org/10.1111/nph.12942>

Parr, C. L., Lehmann, C. E. R., Bond, W. J., Hoffmann, W. A. and Anderson A. N. 2014. Tropical grassy biomes: misunderstood, neglected, and under threat. Trends in Ecology \& Evolution 4: 205-213.

<http://dx.doi.org/10.1016/j.tree.2014.02.004>

Perrier de la Bâthie, H. 1921. La Végétation Malgache. Annales du Musée Colonial de Marseille, 3e série, 9: 1-266.

Sage, R. F. 2004. The evolution of $\mathrm{C}_{4}$ photosynthesis. New Phytologist 161 341-370. <http://dx.doi.org/10.1111/j.1469-8137.2004.00974.X>

Sage, R. F., Wedin, D. A. and Li, M. 1999. The biogeography of $C_{4}$ photosynthesis: patterns and controlling factors. In: $\mathrm{C}_{4}$ Plant Biology. R. F. Sage and R. K. Mouson (eds.), pp 313-373. Academic Press, Cambridge, USA.

Sandel, B., Monnet, A.-C., Govaerts, R. and Vorontsova, M. S. 2017. Late Quaternary climate stability and the origins and future of global grass endemism. Annals of Botany 119: 279-288. <http://dx.doi.org/10.1093/aob/mcw178>

Strömberg, C. A. E. 2011. Evolution of grasses and grassland ecosystems. Annual Review of Earth and Planetary Sciences 39: 517-544. <http://dx.doi.org/10.1146/annurev-earth-040809-152402>

Thiers, B. 2015. Index herbariorum. A global directory of public herbaria and associated staff. New York Botanical Garden's Virtual Herbarium. Available at <http://sweetgum.nybg.org/ih>

Veldman, J. W. 2016. Clarifying the confusion: old-growth savannahs and tropical ecosystem degradation. Philosophical Transactions of the Royal Society B 371: 20150306. <http://dx.doi.org/10.1098/rstb.2015.0306>

Veldman, J. W., Buisson, E., Fernandes, G. W., Durigan, G., Le Stradic, S., et al. 2015. Toward an old-growth concept for grasslands, savannas, and woodlands. Frontiers in Ecology and the Environment 13: 154-162. $<$ http://dx.doi.org/10.1890/140270>

Visser, V., Woodward, F. I., Freckleton, R. P. and Osborne, C. P. 2012. Environmental factors determining the phylogenetic structure of $\mathrm{C}_{4}$ grass communities. Journal of Biogeography 39, 2: 232-246. <http://dx.doi.org/10.1111/j.1365-2699.2011.02602.x>

Vollesen, K. 1980. Annotated check-list of the vascular plants of the Selous Game Reserve, Tanzania. Opera Botanica 59: 1-117.

Vollesen, K., Abdallah, R., Coe, M. and Mboya, E. 1999. Checklist: vascular plants and pteridophytes of Mkomazi. In: Mkomazi: The Ecology, Biodiversity and Conservation of a Tanzanian Savanna, pp. 81-116. Royal Geographical Society, London, UK.

Vorontsova, M. S. and Rakotoarisoa, S. E. 2014. Endemic non-bambusoid genera of grasses (Poaceae) in Madagascar: review of current knowledge. Malagasy Nature 8: 14-34.

Vorontsova, M. S., Ratovonirina, G. and Randriamboavonjy, T. 2013. Revision of Andropogon and Diectomis (Poaceae, Sacchareae) in Madagascar and the new Andropogon itremoensis from the Itremo Massif. Kew Bulletin 68 : 193-207. <http://dx.doi.org/10.1007/s12225-013-9443-3>

Vorontsova, M. S., Besnard, G., Forest, F., Malakasi, P., Moat, J., et al. 2016. Madagascar's grasses and grasslands: anthropogenic or natural? Proceedings Royal Society, Series B 283: 20152262. <http://dx.doi.org/10.1098/rspb.2015.2262>

Willis, K. J., Gillson, L. and Virah-Sawmy, M. 2008. Nature or nurture: the ambiguity of C4 grasslands in Madagascar. Journal of Biogeography 35: 1741-1742. <http://dx.doi.org/10.1111/j.1365-2699.2008.01985.x>

Williams, E., Ntandu, J. E., Ficinski, S. and Vorontsova, M. S. 2016. Checklist of Serengeti Ecosystem Grasses. Biodiversity Data Journal 4: e8286. <http://dx.doi.org/10.3897/BDJ.4.e8286>

World Checklist of Selected Plant Families. 2017. World Checklist of Selected Plant Families. Facilitated by the Royal Botanic Gardens, Kew. Available at $<$ http://apps.kew.org/wcsp>

* Please contact the authors for a pdf of these unpublished reports

\section{SUPPLEMENTARY MATERIAL}

Available online only

Table S1. List of Poaceae species recorded in the Itremo Massif Protected Area, their habitats, distribution ranges, and photosynthetic types. (Please note that the native versus introduced status of Madagascar's non-endemic grasses is largely unknown and challenging to establish, and the status presented here is a preliminary one with little data available to support it. In contrast, the endemicity data are presented here with support from herbarium work and a literature review)

Supplementary material 1. Key to the subfamilies of grasses found in the Itremo Massif.

Supplementary material 2. Key to the genera of grasses found in the Itremo Massif. 
Table S1. List of Poaceae species recorded in the Itremo Massif Protected Area, their habitats, distribution ranges, and photosynthetic types. Please note that the native versus introduced status of Madagascar's non-endemic grasses is largely unknown and challenging to establish, and the status presented here is a preliminary one with little data available to support it. In contrast, the endemicity data are presented here with support from herbarium work and a literature review.

\begin{tabular}{|c|c|c|c|c|}
\hline $\mathbf{N}$ & Species & Habitat & Distribution & $\begin{array}{l}\text { Photosynthetic } \\
\text { type }\end{array}$ \\
\hline 1 & Acroceras boivinii (Mez) A. Camus & Humid forest & Madagascar & C3 \\
\hline 2 & Adenochloa hymeniochila (Nees) Zuloaga & Gallery forest, rice fields, swamps & Native & C3 \\
\hline 3 & Agrostis elliotii Hook. ex Scott-Elliot & Degraded Tapia forest & Madagascar & C3 \\
\hline 4 & Alloteropsis semialata (R.Br.) Hitchc. & Grassland, pine forest & Native & C4 \\
\hline 5 & Andropogon huillensis Rendle & Seasonally wet places & Native & C4 \\
\hline 6 & Andropogon ibityensis A.Camus & $\begin{array}{l}\text { Tapia forest, rocky outcrops, } \\
\text { roadsides }\end{array}$ & Highlands & C4 \\
\hline 7 & Andropogon ivohibensis A.Camus & Rocky outcrops & Highlands & C4 \\
\hline 8 & Andropogon itremoensis Voronts. & $\begin{array}{l}\text { Tapia forest, rocky outcrops, } \\
\text { roadsides }\end{array}$ & Highlands & C4 \\
\hline 9 & Aristida similis Steud. & $\begin{array}{l}\text { Tapia forest, grassland, fallow fields } \\
\text { and roadsides }\end{array}$ & Madagascar & C4 \\
\hline 10 & Aristida tenuissima A.Camus & $\begin{array}{l}\text { Open wet places, tapia forest, } \\
\text { grassland, fallow fields and roadsides }\end{array}$ & Highlands & C4 \\
\hline 11 & Arundinella nepalensis Trin. & Gallery forest, along river & Native & C4 \\
\hline 12 & Axonopus compressus (Sw.) P.Beauv. & Gallery forest & Likely introduced & C4 \\
\hline 13 & Bothriochloa bladhii (Retz.) S.T.Blake & Roadsides & Native & C4 \\
\hline 14 & Brachiaria arrecta (T.Durand \& Schinz) Stent & Rice fields & Native & C4 \\
\hline 15 & Brachiaria bemarivensis A.Camus & Gallery forest, tapia forest & Madagascar & C3 \\
\hline 16 & Brachiaria epacridifolia (Stapf) A.Camus & Gallery forest & Highlands & C3 \\
\hline 17 & Brachiaria umbellata (Trin.) Clayton & Fallow fields, roadsides & Native & C4 \\
\hline 18 & $\begin{array}{l}\text { Brachypodium madagascariense A.Camus \& } \\
\text { H.Perrier }\end{array}$ & Humid forest & Highlands & C3 \\
\hline 19 & $\begin{array}{l}\text { Calamagrostis emirnensis (Baker) T.Durand \& } \\
\text { Schinz }\end{array}$ & Along river, permanent wet places & Madagascar & C3 \\
\hline 20 & Cenchrus polystachios (L.) Morrone & $\begin{array}{l}\text { Roadsides, fallow fields and tapia } \\
\text { forest }\end{array}$ & Native & C4 \\
\hline 21 & Chloris pycnothrix Trin. & Roadsides and fallow fields & Native & C4 \\
\hline 22 & Chrysopogon serrulatus Trin. & $\begin{array}{l}\text { Roadsides, open grassland, tapia } \\
\text { forest }\end{array}$ & Native & C4 \\
\hline 23 & Coelachne africana Pilg. & Wet places and swamps & Native & C3 \\
\hline 24 & Craspedorhachis africana Benth. & Open grassland, wet places & Native & C4 \\
\hline 25 & Ctenium concinnum Nees & $\begin{array}{l}\text { Tapia forest, grassland, rocky } \\
\text { outcrops, roadsides }\end{array}$ & Native & C4 \\
\hline
\end{tabular}




\begin{tabular}{|c|c|c|c|c|}
\hline $\mathbf{N}$ & Species & Habitat & Distribution & $\begin{array}{l}\text { Photosynthetic } \\
\text { type }\end{array}$ \\
\hline 26 & Cymbopogon caesius (Hook. \& Arn.) Stapf & $\begin{array}{l}\text { Tapia forest, grassland, fallow fields } \\
\text { and roadsides }\end{array}$ & Native & C4 \\
\hline 27 & Cynodon dactylon (L.) Pers. & Roadsides and dry fallow fields & Native & C4 \\
\hline 28 & Cyrtococcum deltoideum (Hack) A.Camus & Wet places, shade & Madagascar & C3 \\
\hline 29 & Digitaria ciliaris (Retz.) Koeler & Grassland, rocky outcrops & Native & C4 \\
\hline 30 & Digitaria longiflora (Retz.) Pers. & $\begin{array}{l}\text { Wet places, tapia forest, fallow fields } \\
\text { and roadsides }\end{array}$ & Native & C4 \\
\hline 31 & Digitaria pseudodiagonalis Chiov. & $\begin{array}{l}\text { Tapia forest, grassland, rocky } \\
\text { outcrops, fallow fields }\end{array}$ & Native & C4 \\
\hline 32 & Eleusine indica (L.) Gaertn. & Grassland, roadsides and fallow fields & Native & C4 \\
\hline 33 & Elionurus tristis Hack. & Dry fallow fields & Madagascar & C4 \\
\hline 34 & Eulalia villosa (Spreng.) Nees & Swamp, grassland, fallow fields & Native & C4 \\
\hline 35 & Eragrostis amabilis (L.) Wight \& Arn. & Roadsides and fallow fields & Native & C4 \\
\hline 36 & Eragrostis aspera (Jacq.) Nees & Dry fallow fields & Native & C4 \\
\hline 37 & Eragrostis atrovirens (Desf.) Trin. ex Steud. & $\begin{array}{l}\text { Gallery forest, tapia forest, roadsides } \\
\text { and dry fallow fields }\end{array}$ & Native & C4 \\
\hline 38 & Eragrostis betsileensis A.Camus & Near stagnant water & Itremo & C4 \\
\hline 39 & Eragrostis capensis (Thunb.) Trin. & $\begin{array}{l}\text { Streamside, tapia forest, roadsides, } \\
\text { fallow fields }\end{array}$ & Native & C4 \\
\hline 40 & Eragrostis hildebrandtii Jedwabn. & Roadsides & Madagascar & C4 \\
\hline 41 & Eragrostis japonica (Thunb.) Trin. & Dry fallow fields & Native & C4 \\
\hline 42 & Eragrostis lateritica Bosser & Tapia forest, roadsides & Highlands & C4 \\
\hline 43 & Eragrostis tenuifolia L. & Roadsides and fallow fields & Native & C4 \\
\hline 44 & $\begin{array}{l}\text { Eriochloa fatmensis (Hochst. \& Steud.) } \\
\text { Clayton }\end{array}$ & Roadsides & Native & C4 \\
\hline 45 & Festuca camusiana St.-Yves & Tapia forest & Highlands & C3 \\
\hline 46 & $\begin{array}{l}\text { Heteropogon contortus (L.) P.Beauv. ex } \\
\text { Roem. \& Schult. }\end{array}$ & Tapia forest, open area, fallow fields & Native & C4 \\
\hline 47 & Heteropogon melanocarpus (Elliott) Benth. & Streamside & Native & C4 \\
\hline 48 & Hickelia madagascariensis A.Camus & Gallery forest & Highlands & C3 \\
\hline 49 & Hyparrhenia newtonii (Hack.) Stapf & Tapia forest, grassland, roadsides & Native & C4 \\
\hline 50 & Hyparrhenia rufa (Nees) Stapf & $\begin{array}{l}\text { Wet places, tapia forest, grassland, } \\
\text { roadsides, fallow fields }\end{array}$ & Native & C4 \\
\hline 51 & $\begin{array}{l}\text { Hyparrhenia schimperi (Hochst.ex A.Rich) } \\
\text { Anderson ex Stapf }\end{array}$ & $\begin{array}{l}\text { Streamside, tapia forest, grassland, } \\
\text { roadsides, fallow fields }\end{array}$ & Native & C4 \\
\hline 52 & Imperata cylindrica (L.) Raeusch. & Wet places, grassland, open area & Native & C4 \\
\hline 53 & Isachne mauritiana Kunth & Humid forest & Native & C3 \\
\hline 54 & Ischaemum polystachyum J.Presl & Along the stream, swamp & Native & C4 \\
\hline 55 & Ischaemum rugosum Salisb. & Rice fields & Likely introduced & C4 \\
\hline
\end{tabular}




\begin{tabular}{|c|c|c|c|c|}
\hline $\mathbf{N}$ & Species & Habitat & Distribution & $\begin{array}{l}\text { Photosynthetic } \\
\text { type }\end{array}$ \\
\hline 56 & Leersia hexandra Sw. & Rice fields, swamp & Native & $\mathrm{C3}$ \\
\hline 57 & Loudetia simplex (Nees) C.E.Hubb. & $\begin{array}{l}\text { Edge of forest, wet places, tapia } \\
\text { forest, grassland, rocky outcrops, } \\
\text { fallow fields, roadsides }\end{array}$ & Native & C4 \\
\hline 58 & Melinis minutiflora P. Beauv. & $\begin{array}{l}\text { Edge of forest, tapia forest, } \\
\text { grassland, rocky outcrops, roadsides, } \\
\text { fallow fields }\end{array}$ & Native & C4 \\
\hline 59 & Melinis repens (Willd.) Zizka & $\begin{array}{l}\text { Tapia forest, open area, roadsides, } \\
\text { fallow fields }\end{array}$ & Native & C4 \\
\hline 60 & Microchloa kunthii Desv. & Wet places, tapia forest, roadsides & Native & C4 \\
\hline 61 & $\begin{array}{l}\text { Oldeania ibityensis (A.Camus) D.Z.Li, } \\
\text { Y.X.Zhang \& Haev. }\end{array}$ & Rocky outcrops & Highlands & C3 \\
\hline 62 & Oldeania sp. nov. & Along river & Highlands & C3 \\
\hline 63 & Oplismenus burmanii (Retz.) P.Beauv. & Fallow fields, undergrowth & Native & C3 \\
\hline 64 & Oplismenus compositus (L.) P.Beauv. & Humid forest & Native & C3 \\
\hline 65 & Oplismenus flavicomus Mez & Humid forest & Madagascar & C3 \\
\hline 66 & Oplismenus hirtellus (L.) P.Beauv. & Humid forest & Native & C3 \\
\hline 67 & Panicum ambositrense A.Camus & Edge of gallery forest & Highlands & C3 \\
\hline 68 & Panicum brevifolium L. & Streamside & Native & C3 \\
\hline 69 & Panicum cinctum Hack. & Wet places, grassland & Highlands & C4 \\
\hline 70 & Panicum ibityense A.Camus & Forest, tapia forest, rocky outcrops & Highlands & C3 \\
\hline 71 & Panicum luridum Hack. ex Scott-Elliot & Wet places, grassland & Highlands & C4 \\
\hline 72 & Panicum mitopus K.Schum. & Gallery forest & Native & C3 \\
\hline 73 & Panicum perrieri A.Camus & Forest, tapia forest, fallow fields & Highlands & C3 \\
\hline 74 & Panicum subhystrix A.Camus & $\begin{array}{l}\text { Wet places, around the rock, shady } \\
\text { place, fallow fields }\end{array}$ & Highlands & C3 \\
\hline 75 & Paspalum scrobiculatum L. & $\begin{array}{l}\text { Wet places, tapia forest, grassland, } \\
\text { roadsides, fallow fields }\end{array}$ & Likely introduced & C4 \\
\hline 76 & Perotis patens Gand. & Roadsides, fallow fields & Native & C4 \\
\hline 77 & Phragmites mauritianus Kunth & Streamside & Native & C3 \\
\hline 78 & $\begin{array}{l}\text { Pseudobromus breviligulatus Stapf ex } \\
\text { A.Camus }\end{array}$ & Humid forest & Madagascar & C3 \\
\hline 79 & Sacciolepis indica (L.) Chase & Gallery forest, wet places, rice fields & Native & C3 \\
\hline 80 & Sacciolepis viguieri A.Camus & Tapia forest & Madagascar & C3 \\
\hline 81 & Saccharum hildebrandtii (Hack.) Clayton & $\begin{array}{l}\text { Edge of the gallery forest, near the } \\
\text { stream }\end{array}$ & Highlands & C4 \\
\hline 82 & Saccharum perrieri (A.Camus) Clayton & Humid forest, near the stream & Highlands & C4 \\
\hline 83 & Schizachyrium brevifolium (Sw.) Buse & Tapia forest, fallow fields & Native & C4 \\
\hline 84 & Schizachyrium sanguineum (Retz.) Alston & $\begin{array}{l}\text { Edge of gallery forest, tapia forest, } \\
\text { grassland, rocky outcrop, roadsides }\end{array}$ & Native & C4 \\
\hline
\end{tabular}


Nanjarisoa, O. P., Besnard, G., Ralimanana, H., Jeannoda, H. V. and Vorontsova, M. S. 2017. Grass survey on the Itremo Massif records endemic central highland grasses. Madagascar Conservation \& Development 12, 1: 34-40. http://dx.doi.org/10.4314/mcd.v12i1.6 Supplementary material

\begin{tabular}{l|l|l|l|l}
\hline $\mathbf{N}$ & Species & Habitat & Distribution & $\begin{array}{l}\text { Photosynthetic } \\
\text { type }\end{array}$ \\
\hline 85 & Setaria bathiei A.Camus & Rocky outcrops & Highlands & C4 \\
\hline 86 & Setaria pumila (Poir.) Roem. \& Schult. & $\begin{array}{l}\text { Tapia forest, swamp, fallow fields, } \\
\text { roadsides, rocky outcrops }\end{array}$ & Likely introduced & C4 \\
\hline 87 & Setaria scottii (Hack.) A.Camus & Forest, wet rocky places & Highlands & C4 \\
\hline 88 & $\begin{array}{l}\text { Setaria sphacelata (Schumach.) Stapf \& } \\
\text { C.E.Hubb. ex Moss }\end{array}$ & Forest, wet places & Native & C4 \\
\hline 89 & Sporobolus centrifugus (Trin.) Nees & $\begin{array}{l}\text { Tapia forest, grassland, roadsides, } \\
\text { fallow fields }\end{array}$ & Native & C4 \\
\hline 90 & $\begin{array}{l}\text { Sporobolus paniculatus (Trin.) T.Durand \& } \\
\text { Schinz }\end{array}$ & Roadsides & Native & C4 \\
\hline 91 & Sporobolus piliferus (Trin.)Kunth & $\begin{array}{l}\text { Tapia forest, rocky outcrops, } \\
\text { roadsides, fallow fields }\end{array}$ & Native & C4 \\
\hline 92 & Sporobolus pyramidalis P.Beauv. & Tapia forest, grassland, roadsides & Native & C4 \\
\hline 93 & Stenotaphrum unilaterale Baker & Undergrowth & Highlands & C4 \\
\hline 94 & Styppeiochloa hitchcockii (A.Camus) Cope & Rocky outcrops & Madagascar & C3 \\
\hline 95 & $\begin{array}{l}\text { Trichanthecium brazzavillense (Franch.) } \\
\text { Zuloaga \& Morrone }\end{array}$ & Forest, wet places, grassland & Native & C3 \\
\hline 96 & Trachypogon spicatus (L.f.) Kuntze & $\begin{array}{l}\text { Humid forest, tapia forest, grassland, } \\
\text { rocky outcrops, roadsides }\end{array}$ & Native & C4 \\
\hline 97 & Trichopteryx dregeana Nees & Forest, swamp, grassland, roadsides & Native & C4 \\
\hline 98 & Tristachya betsileensis A.Camus & Rocky outcrops & Itremo & C4 \\
\hline 99 & Urelytrum agropyroides (Hack.) Hack. & $\begin{array}{l}\text { Grassland, tapia forest, swamp, rocky } \\
\text { outcrop, fallow fields }\end{array}$ & Native & C4 \\
\hline
\end{tabular}


Nanjarisoa, O. P., Besnard, G., Ralimanana, H., Jeannoda, H. V. and Vorontsova, M. S. 2017. Grass survey on the Itremo Massif records endemic central highland grasses. Madagascar Conservation \& Development 12, 1: 34-40. http://dx.doi.org/10.4314/mcd.v12i1.6 Supplementary material

SUPPLEMENTARY MATERIAL 1. Key to the subfamilies of grasses found in the Itremo Massif.

1. Woody stem, usually developed more than $1 \mathrm{~m}$ long or climbing, dimorphic leaves BAMBUSOIDEAE

$\mathbf{1}^{\prime}$. Herbaceous stem, if the stem is woody and more than $1 \mathrm{~m}$ long the leaves are not dimorphic ...... 2

2. Spikelet always with two florets with no rachilla extension....................................................3

$\mathbf{2}^{\prime}$. Spikelet with one to many florets, rachilla extension present or absent ....................................4

3. Upper floret bisexual, lower floret male or sterile..... .PANICOIDEAE

3'. Both florets bisexual MICRAIROIDEAE

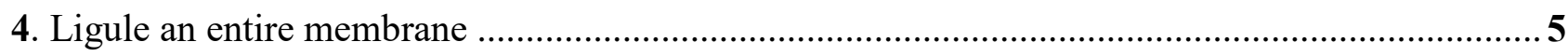

$4^{\prime}$. Ligule a fringe of hairs, with or without membrane ..............................................................6 6

5. Lodicules membranous, nerves widely spaced POOIDEAE

$\mathbf{5}$ '. Lodicules fleshy, narrowly spaced CHLORIDOIDEAE

6. Spikelet with one fertile floret 7

6'. Spikelet with many fertile florets

7. Lemma terminated by a 3 awns forming a column in the base ARISTIDOIDEAE

7'. Lemma awnless, or with one awn, or with many awns but not merged in the base 8

8. Fertile floret subtended by 2 sterile florets EHRHARTOIDEAE (Leersia hexandra) 8'. Fertile floret not subtended by a sterile florets CHLORIDOIDEAE

9. Grasses habitually growing along the river, or small grass typically on the rock or characteristic of inselberg or rocky outcrop ARUNDINOIDEAE 9'. Grasses generally a small size, not typical of inselbergs CHLORIDOIDEAE 
SUPPLEMENTARY MATERIAL 2. Key to the genera of grasses found in the Itremo Massif.

1. Grass with woody stem, dimorphic leaves

(Hickelia, Oldeania)

1'. Grass with herbaceous stem, leaves not dimorphic 3

2. Stem climbing.... Hickelia (madagascariensis)

2'. Stem erect Oldeania (2)

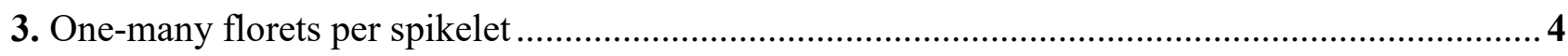

3'. Always 2 florets per spikelet, lower floret male or sterile, upper floret bisexual.....................21

4. Spikelet with one bisexual floret.........................................................................................5

(Aristida, Leersia, Sporobolus, Calamagrostis, Agrostis, Microchloa, Ctenium, Perotis,

Craspedorhachis, Chloris, Cynodon)

4'. Spikelet with 2 to many bisexuals florets

(Phragmites, Styppeiochloa, Eragrostis, Eleusine, Brachypodium, Festuca, Pseudobromus)

5. Lemma with 3 awns Aristida (2)

5'. Lemma awnless or with one awn 6

6. Lemma coriaceous, glumes absent. Leersia (hexandra)

6'. Lemma membranous, at least 1 glume present. 7

7. Inflorescence of several racemes distributed along on a central axis .. Craspedorhachis (africana)

7'. Inflorescence a single raceme, digitate raceme, or a panicle. 8

8. Glumes with an oblique awn, inflorescence a solitary raceme Ctenium (concinnum)

8'. Glumes awnless ...9

9. Florets enveloped by glumes, inflorescence a solitary raceme. 10

9'. Florets not enveloped by glumes, inflorescence of digitate racemes 11

10. Inflorescence a curved raceme, lemma awnless

10'. Inflorescence an erect raceme, lemma awned Microchloa (kunthii)

11. Inflorescence a digitate raceme Perotis (patens)

11'. Inflorescence a simple raceme or a panicle 12

12. Lemma awned 13

12'. Lemma awnless Chloris (pycnothrix)

13. At least one the glume longer than floret Cynodon (dactylon)

13'. Both glumes shorter than or equal to the floret

14. Lemma awned; inflorescence an open panicle, soft and light Sporobolus (4) 14'. Lemma awnless, inflorescence a stiff narrow panicle 15(4'). Grass similar to reeds, more than $1 \mathrm{~m}$ tall. 15'. Grass not similar to reeds, less than $1 \mathrm{~m}$ tall Calamagrostis (emirnensis) Agrostis (elliotii) 16. Typical of inselbergs or rocky outcrop, leaves stiff in basal rosette ... Styppeiochloa (hitchcockii) 16'. Not occurring on inselbergs or rocky outcrops, leaves soft and positioned on the culm 17 17. Inflorescence a simple raceme, pedicel 1-3mm long. Brachypodium (madagascariense) 
Nanjarisoa, O. P., Besnard, G., Ralimanana, H., Jeannoda, H. V. and Vorontsova, M. S. 2017. Grass survey on the Itremo Massif records endemic central highland grasses. Madagascar Conservation \& Development 12, 1: 34-40. http://dx.doi.org/10.4314/mcd.v12i1.6 Supplementary material

17'. Inflorescence a panicle or subdigitate racemes, pedicel more than $3 \mathrm{~mm}$ long .......................18

18. Glumes acuminate; inflorescence a fragile pendent panicle .................................................. 19

18'. Glumes rounded to acute; inflorescence an erect panicle or subdigitate raceme .....................20

19. Glumes weakly acuminate, leaf blades with indistinct transverse nerves

Pseudobromus (breviligulatus)

19'. Glumes long-acuminate, leaf blades with clear transverse nerves Festuca (camusiana)

20. Inflorescence of subdigitate racemes, raceme terminated by a fertile spikelet....Eleusine (indica) 20'. Inflorescence a panicle Eragrostis (9)

21(3'). Spikelets break up at maturity, glumes remain on the plant

(Arundinella, Tristachya, Trichopteryx, Loudetia)

21'. Entire spikelets detach at maturity....

(Cenchrus, Cyrtococcum, Sacciolepis, Eriochloa, Acroceras, Panicum, Trichanthecium,

Oplismenus, Alloteropsis, Brachiaria, Paspalum, Axonopus, Melinis, Digitaria, Stenotaphrum,

Saccharum, Imperata, Eulalia, Trachypogon, Chrysopogon, Bothriochloa, Andropogon,

Schizachyrium, Heteropogon, Ischaemum, Cymbopogon, Hyparrhenia, Urelytrum, Elionurus,

Setaria)

22. Ligule a short membrane. Arundinella (nepalensis)

22'. Ligule a line of hairs

23. Lower lemma 5-7-nerved Tristachya (betsileensis)

23'. Lower lemma 3-nerved

24. Lobes of upper lemma awned Trichopteryx (dregeana)

24'. Lobes of upper lemma awnless. Loudetia (simplex)

25(21'). Spikelets solitary, all spikelets similar 26

(Cenchrus, Cyrtococcum, Sacciolepis, Eriochloa, Acroceras, Panicum, Trichanthecium,

Oplismenus, Alloteropsis, Brachiaria, Paspalum, Axonopus, Setaria)

25'. Spikelets paired or in groups of three, spikelets similar or different to one another.

(Saccharum, Imperata, Eulalia, Trachypogon, Chrysopogon, Bothriochloa, Andropogon,

Schizachyrium, Heteropogon, Ischaemum, Cymbopogon, Hyparrhenia, Urelytrum, Elionurus)

26. Spikelets subtended by a thick bristles, bristles falling with the spikelet

Cenchrus (polystachios)

26'. Spikelets not subtended by a thick bristles or subtended by thick bristles which persist on the rachis

27. Upper lemma hyaline to coriaceous at maturity, margins inrolled

(Cyrtococcum, Sacciolepis, Eriochloa, Acroceras, Panicum, Trichanthecium, Oplismenus,

Alloteropsis, Brachiaria, Paspalum, Axonopus, Setaria)

27'. Upper lemma cartilaginous or chartaceous, margins thin and flat

(Melinis, Digitaria, Stenotaphrum)

28. Upper floret laterally compressed Cyrtococcum (deltoideum)

28'. Upper floret dorsally compressed.

29. Inflorescence an open or contracted panicle 30

(Sacciolepis, Setaria, Eriochloa, Acroceras, Panicum, Trichanthecium) 
Nanjarisoa, O. P., Besnard, G., Ralimanana, H., Jeannoda, H. V. and Vorontsova, M. S. 2017. Grass survey on the Itremo Massif records endemic central highland grasses. Madagascar Conservation \& Development 12, 1: 34-40. http://dx.doi.org/10.4314/mcd.v12i1.6 Supplementary material

29'. Inflorescence a raceme

(Oplismenus, Alloteropsis, Brachiaria, Paspalum, Axonopus)

30. Inflorescence a contracted panicle 31

30'. Inflorescence an open panicle

31. Spikelet inflated at the base, no bristles Sacciolepis (2)

31'. Spikelet not inflated at the base, subtended by one to many persistent bristles Setaria (4)

32. Spikelet supported by a globular ring Eriochloa (fatmensis)

32'. Spikelet supported by a stipe or a straight pedicel

33. Upper glume and lower lemma compressed in tip, upper lemma with a crest

Acroceras (boivinii)

33'. Upper glume and lower lemma not compressed in tip, upper lemma without crest 34

34. Inflorescence axis and leaf sheaths with glandular hairs Adenochloa (hymeniochila) 34'. Inflorescence axis and leaf sheaths without glandular hairs 35

35. Ligule a fringed membrane, upper glumes and lower lemma with 7-13 veins. Panicum (8) 35'. Ligule membranous, glumes and lemmas with fewer veins ......Trichanthecium (brazzavillense)

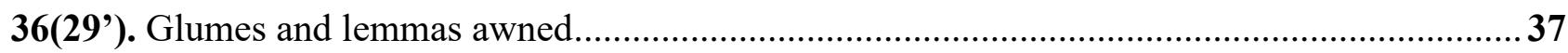

36'. Glumes and lemmas awnless 38

37. Spikelets laterally compressed, glumes without brown transvere streak Oplismenus (4)

37'. Spikelets dorsally compressed, glumes with brown transverse streak....Alloteropsis (semialata) 38. Lower glume present Brachiaria (4)

38'. Lower glume absent. 39

39. Spikelets rounded

Paspalum (scrobiculatum)

39'. Spikelets acute Axonopus (compressus)

40(27'). Spikelets laterally compressed Melinis (2)

40'. Spikelets dorsally compressed 41

41. Inflorescence composed of free digitate or subdigitate racemes Digitaria (3) 41'. Inflorescence composed of reduced racemes on a broad leafy rachis

Stenotaphrum (unilaterale)

42(25'). Internodes of inflorescence rachis and pedicel of pedicelled spikelet are thick and solid.

Urelytrum (agropyroides)

42'. Internodes of inflorescence rachis and pedicel of pedicelled spikelet are thin and loose ..........43

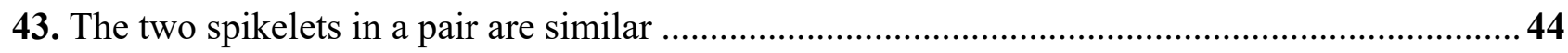

(Imperata, Saccharum, Eulalia)

43'. The two spikelets in a pair are different.

(Trachypogon, Chrysopogon, Bothriochloa, Andropogon, Schizachyrium, Heteropogon, Ischaemum, Cymbopogon, Hyparrhenia, Elionurus)

44. Both spikelets in a pair pedicelled Imperata (cylindrica)

44'. One of the spikelets in a pair sessile

45. Inflorescence a panicle, leaves basal. Saccharum (2)

45'. Inflorescence digitate, leaves present on the culm Eulalia (villosa) 46(43'). Sessile spikelet male or sterile, pedicelled spikelet bisexual and awned 
Nanjarisoa, O. P., Besnard, G., Ralimanana, H., Jeannoda, H. V. and Vorontsova, M. S. 2017. Grass survey on the Itremo Massif records endemic central highland grasses. Madagascar Conservation \& Development 12, 1: 34-40. http://dx.doi.org/10.4314/mcd.v12i1.6 Supplementary material

46'. Sessile spikelet bisexual, pedicelled spikelet male or sterile and awnless

47. Inflorescence a panicle with whorled branches, spikelets in groups of three

Chrysopogon (serrulatus)

47'. Inflorescence a solitary raceme or a digitate or false panicle, spikelets paired 48

48. Pedicel and rachis internode with a translucent line in the middle Bothriochloa (bladhii)

48'. Pedicels and rachis without translucent line in the middle 49

49. Raceme solitary

(Schizachyrium, Heteropogon, Elionurus)

49'. Racemes 2-50.

(Ischaemum, Cymbopogon, Andropogon, Hyparrhenia)

50. Lower glume of sessile spikelet 2-keeled

Schizachyrium (2)

50'. Lower glume of sessile spikelet convex and rounded

51. Racemes with prominent awns Heteropogon (2)

51'. Racemes awnless Elionurus (tristis)

52. Lower floret of sessile spikelets male, palea present Ischaemum (2)

52'. Lower floret of sessile spikelets sterile and reduced to lemma only 53

53. Lower glume of sessile spikelets rounded and furrowed Hyparrhenia (3)

53'. Lower glume of sessile spikelets 2-keeled

54. Racemes retrorse and usually appressed Cymbopogon (caesius)

54'. Racemes erect Andropogon (4) 